\title{
The Essence of Agree in Disagrement: Religious Tolerance in a Multicultural Society
}

\author{
Suryo Ediyono, Muhammad Farkhan Mujahidin, Tri Yanti Nurul Hidayati \\ \{ediyonosuryo@yahoo.com ${ }^{1}$, farchanmd@yahoo.com ${ }^{2}$, nurulhidayati_t@staff.uns.ac.id ${ }^{3}$ \} \\ Faculty of Cultural Sciences (FIB),Universitas Sebelas Maret Surakarta, Indonesia ${ }^{1,2,3}$
}

\begin{abstract}
This article was written with the aim that religious life, especially in Indonesia, can be harmoniously fostered. Coherent life in a pluralistic society will be harmonious if all people of different religions have a tolerance for each other. History records many bloodshed in the name of religion due to the lack of understanding between one another, which should be manifested in an attitude of tolerance. The ethnographic method used refers to a new ethnography that considers events as social and cultural formations of society that exist in stucturing the mind, deeply explored, therefore, they come out of the mind of the research object. This study additionally uses a phenomenological approach. Research with a phenomenological approach seeks to understand the meaning of various events and human interactions in a specific situation. In multicultural societies, followers or adherents of religion play a dominant role in the religious teachings they embrace or even among them there are groups of people who are indifferent to the religion they believe in. Such circumstance can lead into disturbance but also direction toward understanding the existence of a religion along with the bearers. The emergence of interfaith awareness manifested in tolerance can reduce or minimize clashes between communities of different religious views. The motto of "agree in disagreement" is a strong social capital in religious tolerance.
\end{abstract}

Keywords: harmony; multicultural society; religion; tolerance; understanding.

\section{Introduction}

Earth should be a place of residence for people who love peace. Although, the level of peace depends on the people themselves, whether they want to live in harmony and peace or are busy with conflicts and fighting with each other. One factor that contributes significantly to creating the atmosphere of human life is religion. Religion, as a sociological perspective, has many roles and functions, can be constructive and can be destructive. Constructively, religious ties often exceed blood relations and nose or descent relationships. So, because of religion, the community can share a harmonious and peaceful life. Conversely, destructive religion also lies in the power to undermine unity and can even break the ties of brotherhood. Therefore, religious-based conflicts can hardly end [1].

Apart from the dual functions that are reflected in religion, but as humans and religious people must miss life in peace despite living as a multi-religious and faith community. Although harmony between religious believers can only be carried out if everyone from the community respects the values of tolerance. Without tolerance, harmony between religious believers is difficult and even never happened. Indeed, the relationship of tolerance and 
harmony is a causative or causal relationship, thus tolerance is an absolute requirement for the realization of harmony between religious adherents.

There have been many studies that have examined misconceptions about diversity by certain people or groups to trigger tensions between ethnicity, religion, race and groups [2]. For example, there was a conflict between Ambon and Poso (religious conflict), between Sanggau Ledo, Sambas and Sampit (conflict between Dayak, Malay and Madura) and the May 1998 tragedy as "political conflict that resulted in racism, especially sentimentary anti-Chinese attitudes". The same phenomenon also occurs in India, Australia and other countries [3] [4] [5].

One form of diversity found in Indonesia is a matter of religion. Indonesia is not a secular state, nor a religious state, but the recognition of religion by the state only covers six religions, namely Islam, Hindhu, Buddhism, Christianity, Catholicism, and Confucianism. When viewed in terms of the guarantee of religious freedom in the constitution, in fact what is determined by this state is contradictory, since the state actually provides restrictions by determining a certain number of religions that may be embraced, in other words that religion other than those specified cannot live in Indonesia. This is paradoxical.

For residents who embrace the prescribed religion, the state gives respect and appreciation as indicated by the guarantee of religious freedom through the Indonesian Constitution (UUD 1945) and Law No. 39 of 1999 concerning Human Rights (hereinafter referred to as the Human Rights Law). The right to religion (to embrace and practice worship) guaranteed by the Constitution and other laws is not a right that can be exercised at will. This means that there are certain signs or conditions so that the implementation of these rights does not disturb other people's rights, security and order of the community, state, and nation; in other words there are restrictions that must be considered by the population.

The challenge faced in religious development is to apply religious teachings in daily life, to realize internal and inter-religious harmony, and to provide a sense of security and protection from violence. This provision indicates that religious life (as a challenge in the future) is actually like fire in the husk, containing the potential for inter-internal conflict to arise in religious communities, so that the claim of number 7 as above is also questionable.

The Wahid Institute's research found that during 2011, there had been an increase in violations of freedom of religion and belief in various regions in Indonesia. If in the previous year there were only 64 cases, this number increased by $18 \%$ to 92 cases. The highest form of violations of religious freedom is the prohibition or limitation of religious activities or worship activities of certain groups with 49 cases, or $48 \%$, then acts of intimidation and threats of violence by state officials 20 cases or $20 \%$, omission of violence 11 cases $(11 \%)$, violence and coercion of convictions 9 cases (9\%), sealing and prohibition of places of worship 9 cases (9\%), and criminalization or victimization of convictions 4 cases (4\%). State institutions are the perpetrators who commit the most violations of freedom of religion and belief. Of the 92 cases of violations of freedom of religion and belief during 2011, the Ahmadiyya Jama'at was the highest number of victims with 46 cases (50\%), following the GKI Taman Yasmin Bogor congregation 13 cases (14\%), other church congregations 12 cases (13\%), allegedly heretical groups 8 cases (9\%), Millah Abraham (4 cases), Shia groups and AKI (2 cases), Nurul Amal, Bedatuan, Holy Islam, Padange Ati and mosque congregations in NTT (1 case each) . West Java is the highest level of violation of freedom of religion and belief, namely 55 cases or $58 \%$. Followed by Banten, 9 cases or $10 \%$, NAD 5 cases (6\%), East Java, Central Java and South Sulawesi respectively 4 cases, and other areas between $1-2$ cases [1]. 
Based on these data, the issue of religious life in Indonesia is not a simple matter. Tolerance is still a big problem in the midst of competing religions to run the Shari'a and add to its people. Even a harmonious life is also a question mark of its realization.

\section{Method}

This study adopted a qualitative research approach that applied ethnographic methods. The ethnographic method in this study refers to the new ethnographic concept, which considers events as social embodiment and community culture in which various compositions of social minds manifest, to be excavated so that they come out of the mind of the object of research. In addition, this study also uses a phenomenological approach. The study that applies a phenomenological approach seeks to understand the meaning of various events and human interactions in certain situations. Sources of data in this study are human beings with behavior, events, documents, archives and other objects. However, the main data sources in this study are words and actions, the rest are additional data such as documents and others. Data was collected using interactive and non-interactive methods, which were then analyzed using interactive analysis models.In determining the location of the study, researchers collected data through a series of methods such as observation to observe and investigate the occurring empirical facts, interview and the method of documentation to study the socio-religious interaction among the communities, religious leaders and residents living around the Karangduren Village, Klaten, Central Java.

\section{Results and Discussion}

\subsection{Integration between Harmony and Tolerance in Multicultural Society}

The identity of the Indonesian people which is reflected in the slogan "Bhinneka Tunggal Ika" is no longer the diversity of ethnic groups and cultures, but the diversity of cultures that exist in Indonesian society. The main reference for the realization of the multicultural Indonesian society is multiculturalism, which is an ideology that recognizes and glorifies differences in equality, both individually and culturally. Efforts to build a multicultural Indonesia can only be realized if, first, the concept of multiculturalism spreads and is understood as important to the Indonesian people, as well as the desire of the Indonesian people at the national and local levels to adopt and guide their lives; second, the similarity of understanding between experts regarding the meaning of multiculturalism and the building of concepts that support it, and third, the efforts that can be made to realize these ideals [6].

Multiculturalism is defined as recognition and encouragement of cultural pluralism; multi-culture upholds and strives to protect cultural diversity, and at the same time focuses on minority cultural relations with a majority culture that is often unbalanced. In other words, this is a doctrine that emphasizes the advantages of cultural diversity and from the maintenance of cultural wealth. If multiculturalism is applied to policy, multiculturalism includes a series of formal state policies with two main objectives, namely: to maintain harmony between diverse ethnic groups and to structure relations between countries and ethnic minorities [7].

Multiculturalism is not only a discourse, but an ideology that must be fought for because it is needed as a foundation for the upholding of democracy, human rights and the welfare of 
the people. Multiculturalism requires a set of concepts which are the building of concepts to be used as a reference to understand and expand it in social life, such as the concepts of democracy, justice and law, cultural values and ethos, togetherness in equal differences, ethnicity, ethnicity, ethnic culture, religious beliefs, cultural expressions, private and public domains, human rights of cultural communities, and other relevant concepts [6].

It seems that multiculturalism in Indonesia should still be fought for, this can be seen from the amount of violence based on religion, one of the sample phenomena is portrayed in the socio-interaction relationship among the people living in Karangduren village of Kelaten. This acculturation between Javanese or Kejawen beliefs with Islam is often used as a target for certain Islamic groups to attack minority groups under the pretext of purifying Islamic teachings, even though in an Indonesian country that upholds religious freedom, this is not true. The ethics of religious pluralism seems to be insufficient to live on the motherland, in contrast to the ethics of legal pluralism that must be infertile but can still grow. To discuss this problem, it will be done through three approaches, namely the normative theological approach, the dialogical theological approach, and the convergence theology approach.

The normative theological approach to understanding religion literally can be interpreted as an attempt to understand religion by using divinity which departs from a belief in an empirical form of a religion that is considered the most correct compared to others. Amin Abdullah said that theology as we know it cannot certainly refer to a particular religion. Loyalty to the group itself, high commitment and dedication and the use of language that is subjective, namely language as an actor not as an observer is a characteristic inherent in the form of theological thinking. If examined more deeply, within certain religious communities there are still various religious understandings or sects. In Islam itself traditionally, Mu'tazilah, Asy'ariyah and Maturidiyah theology can be found. Previously there were also theologies called Khawarij and Murji'ah [8].

From the above thoughts, it can be seen that the theological approach in religious understanding is an approach that emphasizes formal forms or religious symbols that each claim to be the most correct, while others are wrong. One theological school is so sure and fanatical that its understanding is correct while others understand it wrong, so that it views that others are wrong, misguided, disbelievers, apostates and others.

Establishing understanding, mutual understanding and trust with one another in religious life, is not enough with all three approaches. In building this pluralistic life, especially in religion, it is highly demanded for the harmony of life among fellow believers because the chaos in religious life has the potential to be a barrier to development. There are a number of ideas put forward to achieve peace and harmony in religious life, among them is the idea of "agree in disagreement" agreeing on differences. A religious person should believe that the religion that he embraces is the best and most true religion, and others are also welcome and even appreciated to believe and believe that the religion he professes is the best and the most true religion. Because if you do not believe that the religion that he embraces is the best and right religion, then it is a "foolishness" for the followers of that religion. Religion must be an "acute fever", only religion is useful for its adherents. We want to acknowledge that despite the differences between one religion and another, there are still many similarities [9].

The discussion on religious freedom in the perspective of sociocultural anthropology means learning about "other cultures" in all aspects of humanity so that from the results of the study they can reflect on who they are. Researchers can learn about the point of view, about weltanschaung, about belief, about their cultural values, according to their point of view, so that researchers can understand them in real terms, and thus researchers can communicate with them, and so can expand and develop discourse insights humanity [10]. 
Building trust between humans so that they do not easily act violently or anarchically is basically related to culture. Culture in the study of cultural development is an 'ideational system' or 'system of ideas', or the state of mind that encourages behavioral patterns that are typical of a particular social group. Culture, at one time in an independent variable position when linked to the economic progress of a society. However, even culture can be engineered through public policy, so culture changes to a dependent variable. The right place for culture is as expressed by Daniel Patrict Moynihan that central The central conservative truth is that it is culture, not politics, that determines the success of a society. The central liberal truth is that politics can change culture and save it from itself [6] [11].

\subsection{Tolerance as an embodiment of Religious Consciousness}

In a multicultural society, followers or adherents of religion play a dominant role in the religious teachings they embrace or even among them there is a group of people who are indifferent to the religion they embrace. This kind of condition will disturb and also help understand the existence of a religion with its people. Religious tolerance is the realization of the expression of religious experience in the form of a community [12]. The Expression of religious experience in such a group form, according to Joachim Wach, is the response of religious people to absolute reality which is realized in the form of social relations between religious people or different religions, in order to prove that for them absolute reality is a vital element of human religiosity in social relations, and this there are in every religion, both those who are still alive and those who are already extinct. According to Fritjhof Schuon, the exoteric religion born in this world is different. However, regardless of differences that arise in religions, esoteric [13]. Esoteric is an understanding that basically the religions in the world, both extinct and visible now, have the same purpose in mind that is towards one God. This concept was conceived by Frithjof Schuon in his work "The Transcendent Unity of Religions". The Schuon way of distinguishing these two aspects of religion can be applied as a guide to how humans of different religions meet each other in giving their role as servants of the One God in this world [7]. Tolerance is a form of accommodation in social interaction [14]. Humans are socially religious and cannot deny that they must associate not only with their own groups, but also with different religious groups. Religious people must strive to create tolerance to maintain social stability so that there are no ideological and physical clashes between people of different religions.

The emergence of interfaith awareness manifested in tolerance can reduce or minimize clashes between them. The motto of "agree in disagreement" is a strong social capital in religious tolerance. Religious tolerance developed not only respects the theology and faith of each religion and religious community, but also understands and respects the culture of the religious community. Religious tolerance is able to provide support for the formation of civil society inspired by supernatural values (c.f.[9]).

In a multicultural society, followers or adherents of the religion play a dominant role in the religious teachings they embrace or even become a group of people who are indifferent to the religion they embrace. This kind of condition will be disturbing. There are two groups of religious communities in a multicultural society, namely religious communities educated people and religious ordinances. These two religious communities differ in treating the religion they embrace. For religious people educated people, understanding religious teachings must include rational analysis and intuitive and symbolic understanding. They are easily invited to tolerate religion and adherents of other religions. On the contrary, religious people ordiniary religious teachings full understanding of symbols and do not use rational analysis. 
They are easily ignited by emotions and are very difficult to tolerate with religion and adherents of other religions. This group is easily moved by a group of people or communities who are allied in politics and social culture.

\subsection{The concept of Agree in Disagreement: Pluralism in Indonesia}

Sociologically, religious pluralism is a fact that we are different, diverse and plural in terms of religion. This is a social reality, something that is undeniable and undeniable. In social reality, we have embraced different religions. This recognition of the existence of sociological religious pluralism is the simplest pluralism, because this recognition does not mean allowing recognition of the truth of theology or even ethics of other religions.

As was emphasized by M. Rasjidi that religion is a problem that cannot be bargained, let alone change [15]. He likens religion not as (like) a house or clothing that can be replaced if necessary. If someone embraces belief, then that belief cannot be separated from it [16]. Based on this belief, religious people are difficult to speak objectively in religious matters, because humans are involved (involved). As a Muslim for example, he fully realizes that he is involved (involved) with Islam [16]. However, Rasjidi admitted that in reality the history of the community was multi-complex which contained religious pluralism, various religions. This is reality, because it is inevitable that we must adjust, by recognizing the existence of religious pluralism in Indonesian society [16].

This sociological recognition of pluralism was also stated by Mukti Ali. Mukti Ali socially does not question pluralism, in the recognition of social recognition, but he is very strict in theological matters. He asserted that belief in theological matters cannot be used as a compromise law. Therefore, on the same issue (object), each adherent of religion has different points of view, for example the views on the Qur'an, the Bible, the Prophet Muhammad, Jesus and Mariam. According to him, Muslims make high appreciation for Mariam and Jesus. That is part of the faith of Muslims. Muslims cannot really believe the divinity of Jesus Christ but believe in his prophethood as the Prophet Muhammad. Then, Muslims also not only look at the Qur'an but also the Torah and the Gospel as the Scriptures (Kitabullah). The problem is whether the present Biblical book is authentic or not, and whether it is all God's revelation. This does not mean that Muslims always reject the revelation of God revealed to the Prophet Moses, Isa or other apostles, even though Muslims cannot acknowledge that the Bible as before them today consists of the entire Kalam of God. However, Muslims believe that the Bible contains / contains the Word of God [5].

Especially in this case, Mukti Ali intends to emphasize the idea that every religion has a theological belief that basically uncompromiseable. Islam has its own nuances of belief, even including things that are believed by other religions, such as the concept of Prophet Isa. Likewise, Christians have their own faith, even including things believed by Islam, such as the concept of the Prophet Muhammad. Thus, the recognition of pluralism regarding individual beliefs is at the social level, namely that we sociologically have our own faith and beliefs. As for the truth is the responsibility of each religion.

Mukti Ali explained that there are some thoughts put forward by people to achieve harmony in religious life. First, syncretism, namely the opinion that all religions are the same. Second, reconception, which is to explore and review religion itself in confrontations with other religions. Third, synthesis, which is to create a new religion whose elements are taken from various religions, so that each religion feels that some of its religious teachings have been taken in the synthesis (mixed) religion. Fourth, replacement, namely recognizing that his own religion is right, while other religions are wrong; and try so that other people of religion 
are included in their religion. Fifth, agree in disagreement (agreeing on differences), namely believing that the religion embraced is the best religion, and allowing others to believe that the religion they embrace is the best religion. It is believed that between one religion and another religion, in addition to differences, there are also similarities [9].

\section{Conclusion}

Tolerance is a typical social realization that can accommodate social interactions between multicultural and multireligious communities. Religious people, socially and cannot deny that they must associate their beliefs not only at the level of their own group, but also against other groups of different beliefs. Religious people must struggle to create tolerance to maintain social stability so that there are no ideological and physical clashes between people of different religions. In a multicultural society, followers or adherents of religion play a dominant role in the religious teachings they profess or even among them there are groups of people who are indifferent to the religion they believe in. Such conditions will interfere and also help understand the existence of religion with its people. The emergence of interfaith awareness manifested in tolerance can reduce or minimize clashes between them. The motto "agree in disputes" is strong social capital in religious tolerance. All religions want their followers to live in a peaceful and happy life so that they are not justified in carrying out anarchic actions, especially if they kill each other. Such religious demands can be answered when understanding religion is a normative, dialogical and convergent theological approach that can solve problems that conceptually appear.

\section{References}

[1] T. W. Institute, "Laporan Kebebasan Beragama Dan Toleransi Di Indonesia. The Wahid Institute 2011 "Lampu Merah Kebebasan Beragama," 2011.

[2] P. F. Bangwayo-Skeete and P. Zikhali, "Social tolerance for human diversity in SubSaharan Africa.," Int. J. Soc. Econ., vol. 38, pp. 516-536, 2011.

[3] S. Croucher, "Muslim and Christian conflict styles in Western Europe.," Int. J. Confl. Manag., vol. 22, p. 60-74., 2011.

[4] A. Croucher, S. M., Holody, K. J., Hicks, M. V., Oommen, D., \& DeMaris, "An examination of conflict style preferences in India.," Int. J. Confl. Manag., vol. 22, pp. 10 34, 2011.

[5] A. Mukti Ali, "Dialog between Muslims and Christians in Indonesia and its Problems," in Al-Jami’ah, 1970.

[6] P. Suparlan, "Paradigma Naturalistik dalam Penelitian Pendidikan: Pendekatan Kwalitatif dan Penggunaannya,” Antropol. Indones., vol. 21, 2007.

[7] L. Suryadinata, "Kebijakan Negara Indonesia terhadap Etnik Tionghoa: Dari Asimilasi ke Multikulturalisme.," J. Antropol. Indones., vol. 71, pp. 4-5, 2003.

[8] Muhatadin and Mustafa, "Reorientasi Teologi Islam dalam Konteks Pluralisme Beragama (Telaah Kritis dengan Pendekatan Teologis Normatif, Dialogis dan Konvergensif)," J. Hunafa, vol. 3, 2006.

[9] A. Mukti, Ilmu Perbandingan Agama, Dialog Dakwah dan Misi, dalam Burhanuddin Daya dan Herman Leonard Beck. "Ilmu Perbandingan Agama di Indonesia dan Belanda. jakarta: INIS, 1992. 
[10]A. Marzali, "Ilmu Antropologi Terapan bagi Indonesia yang Sedang Membangun," J. Antropol. Indones., vol. 68, 2002.

[11]J. W. Ajawaila, "Orang Ambon dan Perubahan Kebudayaan," J. Antropol. Indones., vol. 61, 2000.

[12]J. Wach, The Comparative Study of Religions. New York: Columbia University Press, 1958.

[13]F. Schuon, The Transcendent Unity of Religions, cet. ke-2. Wheaton: Quest Books Theosophical Publishing House, 2005.

[14]G. C. Kinloch, Sociological Theory: Development and Major Paradigm. Bandung: Pustaka Setia., 2005.

[15]U. Hasyim, Toleransi dan Kemerdekaan Beragama dalam Islam sebagai Dasar Menuju Dialog dan Kerukunan Antar Agama. Surabaya: PT. Bina Ilmu, t.t.

[16]Rasjidi., "Majalah Al-Djami’ah, Nomor Khusus, Mei 1968-," 1968. 